\title{
Ethical Competences of Trainers Continuing Professional Development
}

DOI: 10.15804/tner.2021.63.1.15

\begin{abstract}
The aim of the study was to determine the level of ethical manifestations in trainers of teacher continuing education and to compare trainers' self-evaluations with their evaluations by teachers. The same was measured also in trainers of other adult professional training and participants of that type of education. Research involved 262 participants, and ethical competencies were measured using the Questionnaire of Trainers' Ethical-Humanistic Manifestations by Pavlov and Skúpa (2018). It was found out that the overall level of ethical competencies was high above-average and comparable in both groups of trainers. Trainers of teacher continuing education statistically significantly overestimated themselves in comparison with how teachers perceived them as participants of the continuing professional development. A similar phenomenon was observed also in trainers of other professional training, although less significant. From the point of view of trainees, trainers of teacher continuing development were evaluated in some measured aspects worse than trainers of other professional training.
\end{abstract}

Key words: teacher professional development, trainer, ethical competencies

\section{Introduction}

Pedagogical or andragogical professions belong to such types of professions where decisions about human affairs and the maintenance of human dignity are 
made. Siegel (2000) points to the fact that in the nineties a number of authors criticized the adult education literature for omitting ethical aspects of this work, that was also reflected in a discussion about the need to develop a universal code of ethics for adult educators. It is also shown in the efforts of the various groups which are trying to develop ethical guidelines for practice (Ianinska \& Garcia, 2006) - e. g. The Coalition of Adult Education Organizations (1993), Michigan Adult and Community Educators (1994), the Association for Adult and Continuing Education (2000), Northern Academy of Human Resource Development (1999).

The importance of the ethical dimension can be seen in several definitions of adult educator competencies (Religa, 2014; Evans, 2012). ESCO (2018), for instance, presents skills of a further education teacher that are closely associated with humanistic principles of education such as respect, tolerance, positive feedback, encouragement of self-confidence or creation of a favourable socio-emotional climate. According to results of the European project AGADE (2006), qualities of a good adult educator include, in addition to professional, expert, didactic and organizational skills, also criteria of personal and ethical development including self-esteem, tolerance, responsibility, communication skills, empathy or flexibility. Also based on the above, Pavlov and Skúpa (2018 - based on the taxonomy by Švec, 1997) published a complex system of trainer ethical-humanistic manifestations including ten dimensions: (1) emotionalization of education; (2) transfer of enthusiasm and vitality to learners; (3) stimulation of learners' purposefulness, independence and creativity; (4) respect for learners' uniqueness; (5) encouragement of learners' self-confidence and help in the development of positive self-esteem; (6) toleration of learners' different opinions, attitudes and cultural styles; (7) positive feedback to learners; (8) learners' moral socialization and development of their cultural behaviour and pro-social conduct; (9) creation of a favourable socio-emotional climate and stimulating educational environment; (10) trainer's professionalism.

An important target group of adult education includes also teachers (hereinafter Ts) for whom ethics is, in terms of the humanistic approach, of great importance within their training for the exercise of the teaching profession. If we want to develop Ts' competencies in all aspects, then it is important to concentrate also on the development of ethical competencies (hereinafter ECs) and Ts' ethical profiles (e. g. Gulevska \& Atanasoska, 2015). As for the discourse about T professionalization, many professionals even believe that emotional maturity, ethics and knowledge of ethical standards of the profession are the basic requirement for 
the exercise of professional practice (e. g. Bruneau, 1998; Campbell, 2013). In this context, we emphasize that the trainer acts as a model for the Ts themselves, which is an important aspect because subsequently Ts act as models for pupils and have the responsibility not only to pass knowledge but also develop learners as valuable good human beings (Campbell, 2003;Schwarz, 1998). Ironically, the right training and Ts development for the ethical profile is difficult to grasp variable, both in terms of its conceptualisation, and as a link to useful content and their use in practice (Sanger \& Osguthorpe, 2011). Warnick and Silverman (2011) point also to the fact that although the development of ECs in Ts is a tool for avoiding relativism and moral decay, it requires a multidimensional approach while overemphasis of highly structured ethical reasoning can undervalue narrative moral sensitivity.

\section{Research problem and objectives of the study}

Jeder argues that training of Ts involves on the one hand training attitudes and skills specific to the psycho-didactic dimensions, but, on the other hand, the formation of ECs that naturally complete the profile of good and devoted Ts, is of the same importance. However, she points out to frequent signals coming from the media, parents and professionals who speak about insufficient importance attributed to this topic and leading to the following questions: How well do Ts report to the ethical rules of the profession they exercise? How much attention is given to the initial and continuous training of this dimension? What is the impact of the lack of consistent training and development of Ts' ECs on education and society in general? Of course, answers to these questions have been sought for by many authors. Chapman, Foster and Buchanan (2013), e. g. investigate the quality of moral imagination in pre-service Ts, Kuusisto, Tirri and Rissanen (2012) measure ethical sensitivity in student teachers and Ts in practice, Boon and Lewthwaite (2016) focus on ethical aspects of multicultural education, Hilmi KOÇ \& Fidan (2020) study the level of institutionalization of ethical rules in schools. While, from the Ts' perspective, the EC level increases with increasing practice (Kuusisto, Tirri \& Rissanen, 2012), some studies point out that pupils and students may perceive the fact somewhat more negatively when evaluating Ts (Ozean, Balyer \& Servi, 2013). Moreover, research on the issue frames rather $T$ training and practice, but only occasionally reaches to the level of trainers of $\mathrm{T}$ continuing development, which, however, is not negligible.

In the context of the defined research problem, the presented study was set up with the following objectives: to (1) determine the level of ethical manifestations in trainers of 'Ts' continuing development through introspection, and compare 
the trainers' self-evaluations with their evaluations by Ts; (2) determine the level of ethical manifestations in a different type of adult education trainers (other professions) through introspection and compare the trainers' self-evaluations with their evaluations by their trainees; and (3) compare evaluations of trainers of $\mathrm{T}$ continuing development and trainers of other professional training in the level of ethical manifestations by trainees of the respective training type.

\section{Methodology of Research}

The study is empirical descriptive quantitative research focusing on comparative analyses. The sections below describe the principles of sample selection, methods of collection as well as methods of data analyses.

\section{Characteristics of the research sample}

The research was carried out in 2019, using a combination of convenience and deliberate sampling and involving 262 people in total. The main research sample included 103 people in total, these trainers of $\mathrm{T}$ continuing education and their trainees - thus Ts. There were 24 trainers ( 8 men, 16 women, mostly from 36 to 45 years old). The comparative research sample included 159 people, out of it 29 trainers of further professional training and re-qualification courses in accredited training programmes (18 men, 11 women, mostly from 36 to 45 years old) and 130 trainees of this type of training ( 54 men and 76 women, mostly from 18 to 35 years old). All participants signed informed consent. Represented were all regions of Slovakia.

\section{Methods of data collection and analyses}

To determine the level of EC in trainers and trainees, the questionnaire by Pavlov and Skúpa (2018) was used, with 43 items in total and a 7-point scale (1 I do not agree at all, 7 - I absolutely agree), measuring 10 dimensions (see above) in addition to the total score, with uneven representation of related statements (Table 1). The value of internal consistency for the whole questionnaire was 0.971 (Cronbach Alpha), indicating high stability of measurement. Values of individual sub-scales were from 0.618 to 0.884 . To analyze data, the program SPSS and procedures of descriptive and inferential statistics were used. Non-parametric versions of statistical comparison tests were used because sizes of participants' groups were highly heterogeneous. 
Table 1. Overview of questionnaire dimensions

\begin{tabular}{|c|c|c|c|}
\hline Dimension & Item example & $\begin{array}{l}\text { Number } \\
\text { of Items }\end{array}$ & $\begin{array}{l}\text { Reliabil- } \\
\text { ity }\end{array}$ \\
\hline $\begin{array}{l}\text { Emotionalization } \\
\text { of the training }\end{array}$ & $\begin{array}{l}\text { I expressively convey the practical meaning of the } \\
\text { subject matter (e. g. emotionally coloured words. } \\
\text { impressive intonation. expressive gestures) }\end{array}$ & 5 & 0.747 \\
\hline $\begin{array}{l}\text { Transfer of en- } \\
\text { thusiasm }\end{array}$ & $\begin{array}{l}\text { I show enthusiasm for helping learners and creating } \\
\text { their good }\end{array}$ & 3 & 0.618 \\
\hline $\begin{array}{l}\text { Stimulation of } \\
\text { independence }\end{array}$ & $\begin{array}{l}\text { I enable learners to be critical in any teaching } \\
\text { situation }\end{array}$ & 4 & 0.782 \\
\hline Individualization & $\begin{array}{l}\text { I place reasonable demands on learners with regard } \\
\text { to their individual differences }\end{array}$ & 5 & 0.857 \\
\hline $\begin{array}{l}\text { Encouragement } \\
\text { of self-confidence }\end{array}$ & $\begin{array}{l}\text { I show belief in learners' potentials (point to their } \\
\text { strengths. potentials. gifts. talents). }\end{array}$ & 3 & 0.798 \\
\hline $\begin{array}{l}\text { Toleration of dif- } \\
\text { ferent opinions }\end{array}$ & $\begin{array}{l}\text { I play rather the role of a debater than that of an } \\
\text { arbitrator in case of opposing opinions. }\end{array}$ & 5 & 0.795 \\
\hline $\begin{array}{l}\text { Positive evalu- } \\
\text { ation }\end{array}$ & $\begin{array}{l}\text { I attempt to find positive elements also in learners' } \\
\text { incorrect answers. }\end{array}$ & 4 & 0.884 \\
\hline $\begin{array}{l}\text { Moral socializa- } \\
\text { tion }\end{array}$ & $\begin{array}{l}\text { I give examples of fair. responsible. tolerant and } \\
\text { welcoming persons. }\end{array}$ & 4 & 0.809 \\
\hline $\begin{array}{l}\text { Creation of a fa- } \\
\text { vourable climate }\end{array}$ & $\begin{array}{l}\text { I generate an atmosphere of mutual openness and } \\
\text { trust. }\end{array}$ & 5 & 0.836 \\
\hline $\begin{array}{l}\text { Trainer profes- } \\
\text { sionalism }\end{array}$ & $\begin{array}{l}\text { I do not comment negatively on my colleagues' } \\
\text { professionalism. }\end{array}$ & 5 & 0.662 \\
\hline
\end{tabular}

\section{Research Results}

Table 2 presents results of the analysis comparing self-evaluations of ethical manifestations by trainers of $\mathrm{T}$ continuing education with views of Ts who participated in this type of education. Using the Mann-Whitney U-test, statistically significant differences were identified in all measured dimensions as well as in the questionnaire total score - trainers considerably overestimated their ECs; the total level of ECs achieved by trainers was above average from the point of view of both the trainers themselves and their trainees, thus Ts. The biggest differences (trainers' self over-estimation) were noted in the dimensions emotionalization of the training, individualization, positive feedback, creation of a favourable climate and trainer professionalism. 
Table 3 presents results of the analysis comparing self-evaluations of trainers of further professional training and re-qualification courses in accredited educational programmes with views of participants in this type of education. Using the Mann-Whitney U-test, statistically significant differences were identified in all measured dimensions as well as in the questionnaire total score - trainers considerably overestimated their ECs, the total level of ECs achieved by trainers was above average from the point of view of both the trainers themselves and their trainees. The biggest differences (trainers' self over-estimation) were noted in the dimension's encouragement of self-confidence, toleration of different opinions, creation of a favourable climate and trainer professionalism.

Table 4 presents results of the analysis comparing evaluation of both trainer groups from the point of view of participants of the relevant type of training. The Mann-Whitney U-test showed that according to trainees the total level of ethical manifestations was above average in both trainer groups and comparable in both cases. Also, statistically significant differences were found in the dimensions emotionalization of the training and individualization, creation of a favourable climate and trainer professionalism - the dimensions were evaluated worse for trainers of $\mathrm{T}$ continuing education.

Table 2. Comparison of CE trainers and trainees (Ts)

\begin{tabular}{|c|c|c|c|c|}
\hline Dimension & Group & MDN & Test result & SIG. \\
\hline \multirow[t]{2}{*}{ Emotionalization of the training } & CE trainer & 30 & \multirow[t]{2}{*}{4.186} & \multirow[t]{2}{*}{0.000} \\
\hline & CE trainee & 25 & & \\
\hline \multirow[t]{2}{*}{ Transfer of enthusiasm } & CE trainer & 16.5 & \multirow[t]{2}{*}{2.122} & \multirow[t]{2}{*}{0.034} \\
\hline & $\mathrm{CE}$ trainee & 15.0 & & \\
\hline \multirow[t]{2}{*}{ Stimulation of independence } & CE trainer & 22.5 & \multirow[t]{2}{*}{3.241} & \multirow[t]{2}{*}{0.001} \\
\hline & CE trainee & 20.0 & & \\
\hline \multirow[t]{2}{*}{ Individualization } & CE trainer & 29 & \multirow[t]{2}{*}{3.864} & \multirow[t]{2}{*}{0.000} \\
\hline & CE trainee & 25 & & \\
\hline \multirow[t]{2}{*}{ Encouragement of self-confidence } & CE trainer & 17.5 & \multirow[t]{2}{*}{3.308} & \multirow[t]{2}{*}{0.001} \\
\hline & CE trainee & 15.0 & & \\
\hline \multirow[t]{2}{*}{ Toleration of different opinions } & CE trainer & 30 & \multirow[t]{2}{*}{4.643} & \multirow[t]{2}{*}{0.000} \\
\hline & CE trainee & 24 & & \\
\hline \multirow[t]{2}{*}{ Positive evaluation } & CE trainer & 23.5 & \multirow[t]{2}{*}{4.028} & \multirow[t]{2}{*}{0.000} \\
\hline & CE trainee & 19.0 & & \\
\hline \multirow[t]{2}{*}{ Moral socialization } & CE trainer & 22.5 & \multirow[t]{2}{*}{3.364} & \multirow[t]{2}{*}{0.001} \\
\hline & CE trainee & 18.0 & & \\
\hline
\end{tabular}




\begin{tabular}{|c|c|c|c|c|}
\hline Dimension & Group & MDN & Test result & SIG. \\
\hline \multirow[t]{2}{*}{ Creation of a favourable climate } & CE trainer & 31 & 4.367 & 0.000 \\
\hline & CE trainee & 24 & & \\
\hline \multirow[t]{2}{*}{ Trainer professionalism } & CE trainer & 29.5 & 4.530 & 0.000 \\
\hline & CE trainee & 22.0 & & \\
\hline \multirow[t]{2}{*}{ Total score } & CE trainer & 252.5 & 4.584 & 0.000 \\
\hline & CE trainee & 203.0 & & \\
\hline
\end{tabular}

Legend: CE - continuing education; MDN - median; SIG - statistical significance, Test result - result of the Mann-Whitney U-test

Table 3. Comparison of PT trainers and trainees

\begin{tabular}{|c|c|c|c|c|}
\hline Dimension & Group & MDN & Test result & SIG. \\
\hline \multirow[t]{2}{*}{ Emotionalization of the training } & PT trainer & 29 & 2.889 & 0.004 \\
\hline & PT trainee & 26 & & \\
\hline \multirow[t]{2}{*}{ Transfer of enthusiasm } & PT trainer & 17 & 2.151 & 0.032 \\
\hline & PT trainee & 16 & & \\
\hline \multirow[t]{2}{*}{ Stimulation of independence } & PT trainer & 23 & 3.197 & 0.001 \\
\hline & PT trainee & 21 & & \\
\hline \multirow[t]{2}{*}{ Individualization } & PT trainer & 29 & 3.314 & 0.001 \\
\hline & PT trainee & 26 & & \\
\hline \multirow[t]{2}{*}{ Encouragement of self-confidence } & PT trainer & 17 & 3.630 & 0.000 \\
\hline & PT trainee & 15 & & \\
\hline \multirow[t]{2}{*}{ Toleration of different opinions } & PT trainer & 28 & 5.164 & 0.000 \\
\hline & PT trainee & 23 & & \\
\hline \multirow[t]{2}{*}{ Positive evaluation } & PT trainer & 23.0 & 2.962 & 0.003 \\
\hline & PT trainee & 20.5 & & \\
\hline \multirow[t]{2}{*}{ Moral socialization } & PT trainer & 22 & 3.136 & 0.002 \\
\hline & PT trainee & 20 & & \\
\hline \multirow[t]{2}{*}{ Creation of a favourable climate } & PT trainer & 29 & 4.184 & 0.000 \\
\hline & PT trainee & 26 & & \\
\hline \multirow[t]{2}{*}{ Trainer professionalism } & PT trainer & 28.0 & 4.530 & 0.000 \\
\hline & PT trainee & 23.5 & & \\
\hline \multirow[t]{2}{*}{ Total score } & PT trainer & 242.0 & 4.584 & 0.000 \\
\hline & PT trainee & 213.5 & & \\
\hline
\end{tabular}

Legend: PT - professional training and re-qualification courses; MDN - median; SIG - statistical significance, Test result - result of the Mann-Whitney U-test 
Table 4. Comparison of CE and PT trainers by trainees

\begin{tabular}{|c|c|c|c|c|}
\hline Dimension & Group & MDN & Test result & SIG. \\
\hline \multirow[t]{2}{*}{ Emotionalization of the training } & CE trainee & 25 & 2.371 & 0.018 \\
\hline & PT trainee & 26 & & \\
\hline \multirow[t]{2}{*}{ Transfer of enthusiasm } & CE trainee & 15 & 1.254 & 0.210 \\
\hline & PT trainee & 16 & & \\
\hline \multirow[t]{2}{*}{ Stimulation of independence } & CE trainee & 20 & 1.931 & 0.053 \\
\hline & PT trainee & 21 & & \\
\hline \multirow[t]{2}{*}{ Individualization } & CE trainee & 25 & 2.387 & 0.017 \\
\hline & PT trainee & 26 & & \\
\hline \multirow[t]{2}{*}{ Encouragement of self-confidence } & CE trainee & 15 & 1.012 & 0.312 \\
\hline & PT trainee & 15 & & \\
\hline \multirow[t]{2}{*}{ Toleration of different opinions } & CE trainee & 23 & 0.258 & 0.797 \\
\hline & PT trainee & 23 & & \\
\hline \multirow[t]{2}{*}{ Positive evaluation } & CE trainee & 19.0 & 1.645 & 0.100 \\
\hline & PT trainee & 20.5 & & \\
\hline \multirow[t]{2}{*}{ Moral socialization } & CE trainee & 18 & 1.827 & 0.068 \\
\hline & PT trainee & 20 & & \\
\hline \multirow[t]{2}{*}{ Creation of a favourable climate } & CE trainee & 24 & 2.195 & 0.028 \\
\hline & PT trainee & 26 & & \\
\hline \multirow[t]{2}{*}{ Trainer professionalism } & CE trainee & 22.0 & 2.126 & 0.033 \\
\hline & PT trainee & 23.5 & & \\
\hline \multirow[t]{2}{*}{ Total score } & CE trainee & 203.0 & 1.906 & 0.057 \\
\hline & PT trainee & 213.5 & & \\
\hline
\end{tabular}

Legend: VT - professional training and requalification courses; CE - continuing education; MDN median; SIG - statistical significance, Test result - result of the Mann-Whitney U-test

\section{Discussion}

The section below presents main findings discussed in the context of our knowledge about the issue. (1) The level of adult education trainers' ECs was above average in both groups of trainers, this from the point of view of the trainers themselves as well as from the point of view of trainees. The results mentioned cannot be compared with other studies since we do not yet know about them. As mentioned above, the issue of ethical aspects of Ts' work tends to be examined more in the context of student teacher training or in the context of monitoring of 
their qualities in the exercise of their profession. ECs of trainers of T continuing education have not been studied so much yet. However, the identified values allow us to state that the measured levels of trainers' ECs create good preconditions for Ts' further professional development and indicate the well-documented fact that education has a deep value character and that educators reflect their own meaning of work through the lens of the moral nature of their profession (see e. g. Beyer, 1997; Campbell, 1997).

(2) Adult education trainers have a tendency to considerably overestimate their ECs in comparison with trainees' views of their behaviour. The findings point to the well known phenomenon called social desirability. Osin (2009) ranks this phenomenon to the topics of positive psychology dealing, by its very nature, with phenomena desirable and appropriate. It is logical to expect that at least some of the persons will tend to self-over-estimate their various qualities, this either unconsciously, with the aim to maintain positive self-perception, or consciously to make a better impression on those around. This effect tends to occur often in the context of questionnaire research and many psychometrists point out to its importance in the context of measurement validity. It cannot be otherwise in the case of our study, since social desirability directly correlates with unethical behaviour precisely in the case of a participant's conscious self over-estimation - thus lying. In this context, we propose the use of a questionnaire completed by one of the existing scales to minimize and control the impact on responses to questionnaires that can distinguish between delusion (which is the honest answer) and pretending to knowledge and exaggeration (for more details see Babinčák, Preiss \& Mejzlíková, 2019). The above is associated also with the finding that (3) the highest tendency to self over-estimation of $\mathrm{T}$ continuing education trainers was noted in the dimension emotionalization of the training, individualization, positive feedback, creation of a favourable climate and trainer professionalism. We consider these results to be so far poorly interpretable since the extent of the impact of social desirability on the measurement, and the internal structure of intentions in over-estimation, if any, cannot be assessed without the above-mentioned scale.

(4) From the point of view of trainees, trainers of T continuing development were evaluated worse in some measured aspects against trainers of other professional training. This finding was surprising and we suggest its further verification and examination in future. However, we are of the opinion that Ts as trainees are a specific and relatively complicated group. It is due to their general professional and psycho-didactic insight into the education and training processes, thus they may be more critical in the roles of evaluators when evaluating a trainer (who 
is first a colleague/competitor and only then authority) than trainees observing the trainer's quality only implicitly and intuitively, e. g. in requalification courses where they concentrate more on the training content, although they understand the importance of the form and method of training in the context of the trainer's professional competence and personality.

Within the discussion, we would like to comment on the limitations of the study. The numbers of participants may be considered low with regard to the ambition of quantitative analyses, which we are aware of. Nevertheless, we believe that it is important to present the results because the samples of participants are specific with respect to the size of the country where the measurement was made, as well as because the data show a high level of content consistency (several conclusions are repeated) and point out to statistically significant differences even with such low variability of data (while the level of statistical significance is positively dependent on the number of participants). Another limitation is that the applied measuring tool has not a satisfactory level of reliability (0.7) in two sub-scales and its structure has not been verified yet. That is the reason why we consider it appropriate to attribute importance especially to the results that relate to the total scores and work with the conception of one-dimensional measurement.

In the end we state that we consider the study to be a stimulating contribution to the current and significant discussion about ethical aspects of andragogical and pedagogical professions. Supporting their ethical dimension emerges as a natural need at the time that many associate with moral decay due to the triumph of the free market causing subordination of social values and education to the requirements of global competition where the actor is no longer man in his particular existential, historical and social position, but an individual as part of a system of economic functions, who chooses his goals and means with a vision of profit maximization. Likewise many other professionals, we, too, believe that it is Ts and trainers providing for their training and further professional development, who play a significant role of corrective elements in these processes - that is why it is necessary to continue to pay this issue consistent research attention.

\section{Acknowledgements}

The contribution was made possible by the financial support from the Slovak Research and Development Agency of the Ministry of Education, Science, Research and Sport of the Slovak Republic and the Slovak Academy of Sciences within the project VEGA 1/0794/19 Professional Identity and Quality of a Higher Education Teacher in the Context of Andragogical Competence. 


\section{References}

Agade (2006). A good adult educator in Europe. Retrieved April 17, 2019, from http://old. nordvux.net/download/1740/manual_for_ae_prac.pdf

Babinčák P., Preiss M. \& Mejzlíková T. (2019). Meranie žiadúceho štýlu odpovedania slovenskou verziou škály BIDR. Vlastnosti konštruktu a overenie súvislostí s morálnym vyviazaním a dalšími premenným.( Measuring Desirable Responding with the Slovak Version of the BIDR Scale. Construct Attributes and Verification of the Relations with Moral Disengagement and Other Variables) Česká a slovenská psychiatrie,115(2), 59-66.

Beyer, L. (1997) The moral contours of teacher education. Journal of Teacher Education, 48(4), 245-254.

Boon, H. \& Lewthwaite, E. (2016). Teacher Ethics: The Link between Quality Teaching and Multi-ethnic and Multiracial Education. Athens Journal of Education, 3 (4), 331-344.

Bruneau, S. (1998). Adding PPP to the preparation of new professionals. Ethics \& Behaviour, 8, 249-267.

Campbell, E. (1997). Connecting the ethics of teaching and moral education. Journal of Teacher Education, 48(4), 255-263.

Campbell, E. (2003). The ethical teacher. Philadelphia: Open University Press.

Campbell, E. (2013). Cultivating moral and ethical professional practice. In M.N. Sanger, R.D. Osguthorpe (Eds.), The moral work of teaching and teacher education: Preparing and supporting practitioners. (pp.29-44). New York: Teachers College Press.

Esco(2018). European Skills/Competences, qualifications and Occupations. Retrieved June 20, 2018, from https://ec.europa.eu/esco/portal/occupation?conceptLanguage=sk\&full=true

Evans, L. (2012). Examining the professionalism of adult educators. Studia paedagogica, 17 (1), 129-147.

Gulevska, V. \& Atanasoska, T. (2015). Enhancing teacher competencies with emotional and capacity. International Journal of Cognitive Research in Science, Engineering and Education. 3 (2), 85-90.

Hilmi KOÇ M. \& Fidan, T. (2020). The Institutionalization of Ethics in Schools: A Qualitative Research on Teachers. Participatory Educational Research, 7 (2), 80-101.

Chapman, A., Foster, D. \& Buchanan, R. (2013). The Moral Imagination in Pre-service Teachers' Ethical Reasoning. Australian Journal of Teacher Education, 38 (5),131-143.

Ianinska, S. \& Garcia, J. (2006). Morals, ethics and integrity: Howcodes of conduct contribute to ethical adult education practice. Public organization review: A Global Journal, 6, 3-20.

Jeder, D. (2014). Training teachers' ethical skills in license and master programs. Procedia - Social and Behavioral Sciences, 142, 691-694.

Kuusisto, E., Tirri, K. \& Rissanen, I. (2012). Finnish Teachers' Ethical Sensitivity. Education Research International, 2012, 1-10.

Osin, E.N. (2009) Social Desirability in Positive Psychology: Bias or Desirable Sociality? In T. Freire (Ed.) Understanding Positive Life. Research and Practice on Positive Psychology. (pp. 421-442). Lisabon: Climepsi Editores. 
Ozcan, K., Balyer, A. \& Servi, T. (2013) Faculty Members' Ethical Behaviors: A Survey Based on Students' Perceptions at Universities in Turkey. International Education Studies, 6 (3), 129-141.

Pavlov, I. \& Skúpa, M. (2018). Categorical observation system of humanistic andragogical work of an adult educator. In L. Tomczyk, A. Ryk (Eds.), New trends and research challenges in pedagogy and andragogy. (pp. 99-108). Kraków: Uniwersytet Pedagogiczny w Krakowie.

Religa, J. (2014). Kompetencje europejskich mentorów i tutorów. Competences of the European mentors and tutors. Edukacja ustawiczna doroslych, 2(85), 36-45.

Sanger, M.N., \& Osguthorpe, R.D. (2011). Teacher education, preservice teacher beliefs, and the moral work of teaching. Teaching and Teacher Education, 27(3), 569-578.

Schwarz, G.E. (1998). Teaching as vocation: Enabling ethical practice. The Educational Forum, 63(1), 23-29.

Siegel, I. (2000). Toward Deweloping A Universal Code of Ethics For Adult Educators. PAACE Journal of Lifelong Learning, 9, 39-64.

Švec, Š. (1997). Koncepcia humanisticky orientovanej výučby. (Conception of humanistically oriented teaching). Pedagogická revue, 1-2, 2-14.

Warnick, B., \& Silverman, S. (2011). A framework for professional ethics course in teacher education. Journal of Teacher Education, 62, 273-285. 